\title{
PENGARUH PENDIDIKAN AKHLAK DALAM KELUARGA TERHADAP KEPRIBADIAN REMAJA AWAL (USIA 12-15 TAHUN)
}

\author{
Ita Nurwidia ${ }^{1}$, Saeful Anwar ${ }^{2}$ \\ IAILM Suryalaya Tasikmalaya - Indonesia \\ itanurwidia12@gmail.com¹,saefulanwar@gmail.com²
}

\begin{abstract}
Abstrack
This study aims to determine the effect of moral education in the family on the personality of early adolescents (aged 12-15 years). The method used in this research is descriptive method through a quantitative approach, namely research that seeks to reveal the current state / condition by considering past conditions through processing the numbers obtained from the study. The population in this study were 135 people and the sample was 34 people. Based on the results of data processing that the effect of moral education in the family on the personality of early adolescents (aged 12-15 years) based on the rs price, the value of 0.64 on the Guilford scale is obtained in the interval $0.61-0.80$ with high classification. Then the hypothesis testing of the effect of moral education in the family affects the personality of early adolescents (aged 12-15 years), it can be explained that the tcount value is greater than t table (tcount $=4.672>$ ttable $=1.69389$, so that Ha is accepted and Ho is rejected), thus It can be explained that the more moral education in the family, the better the personality of early adolescents (ages 12-15 years).
\end{abstract}

Keywords: Moral education, family, personality, early edolescents (ages 12-15 years)

\begin{abstract}
Abstrak
Penelitian ini bertujuan untuk mengetahui pengaruh pendidikan akhlak dalam keluarga terhadap kepribadian remaja awal (usia 12-15 tahun). Metode yang digunakan dalam penelitian ini adalah metode deskriptif melalui pendekatan kuantitatif yaitu penelitian yang berupaya untuk mengungkapkan keadaan/kondisi yang terjadi saat sekarang dengan mempertimbangkan keadaan masa lampau melalui pengolahan angka-angka yang diperoleh dari penelitian, Populasi pada penelitian ini adalah 135 orang dan sampelnya 34 orang. Berdasarkan hasil pengolahan data bahwa pengaruh pendidikan akhlak dalam keluarga terhadap kepribadian remaja awal (usia 12-15 tahun) berdasarkan harga rs diperoleh nilai 0,64 pada skala Guilford berada pada interval 0,61 - 0,80 dengan klasifikasi tinggi. Kemudian pengujian hipotesis pengaruh pendidikan akhlak dalam keluarga mempengaruhi kepribadian remaja awal (usia 12-15 tahun) dapat dijelaskan bahwa diperoleh nilai $t_{\text {hitung }}$ lebih besar dari $t_{\text {tabel }}\left(t_{\text {hitung }}=4,672>t_{\text {tabel }}=1,69389\right.$, sehingga Ha diterima dan Ho ditolak), dengan demikian dapat dijelaskan bahwa smakin banyak pendidikan akhlak dalam keluarga maka semakin baik pula kepribadian remaja awal (usia 12-15 tahun).
\end{abstract}

Kata kunci: pendidikan akhlak, kelurga, kepribadian, remaja awal (usia 12-15 tahun) 


\section{A. PENDAHULUAN}

\section{Latar Belakang Masalah}

Pendidikan akhlak menurut Hasan (2011: 26) adalah internalisasi nilai-nilai kedalam diri anak, sehingga dengan demikian ia membentuk satu kesadaran yang stabil akan apa-apa yang baik dan apa-apa yang buruk, selanjutnya pada saat yang sama pendidikan akhlak juga harus memastikan bahwa nilai-nilai tersebut menemukan perwujudan operasionalnya sehingga secara alamiah dan spontan menjadi bagian dari tingkah laku dalam kehidupan anak tersebut.

Dalam hal ini, peranan orang tua terhadap pendidikan anak sangatlah penting, yaitu dengan memberikan dasar pendidikan, sikap, dan keterampilan, seperti pendidikan agama, budi pekerti, sopan santun, estetika, kasih sayang, rasa aman, dasar-dasar mematuhi peraturan, dan menanamkan kebiasaan-kebiasaan. Setiap orangtua mempunyai tanggung jawab atas kehidupan anak-anak mereka dimasa kini dan masa yang akan datang. Bahkan umumnya para orang tua merasa bertanggung jawab atas segala hal dalam kehidupan anak-anak mereka.

Keluarga juga dituntut mampu menstimulasi berbagai potensi anak dengan berbagai kegiatan yang mampu merangsang seluruh potensinya serta dibekali dengan berbagai kompetensi agar dapat menghadapi tantangan zaman, baik potensi fisik, sosial emosi, bahasa, intelektual, moral, dan lainnya sehingga kelak anak-anak siap menghadapi suasana lingkungan yang sesungguhnya. (Nana, 2018: 9).

Hubungan dan tanggung jawab orang tua kepada anak pada, dasarnya tidak dapat dipikulkan kepada orang lain, termasuk guru dan pemimpin umat (Ulama). Sebab guru maupun ulama hanya berperan sebagai pihak penyerta dalam proses pendidikan seorang anak. Dengan kata lain, tanggung jawab pendidikan yang dipikul oleh pendidik selain orang tua merupakan pelimpahan dari tanggung jawab orang tua yang karena satu dan hal lain tidak mungkin melaksanakan pendidikan anaknya secara sempurna.

Berdasarkan permasalahan yang telah diuraikan diatas maka rumusan masalah sebagai berikut:

a. Bagaimana pendidikan akhlak dalam keluarga di RW.02 Kampung Cibangkerong Desa Mekarmulya Kecamatan Malangbong Kabupaten Garut?

b. Bagaimana kepribadian remaja awal (usia 12-15 tahun) di RW.02 Kampung Cibangkerong Desa Mekarmulya Kecamatan Malangbong Kabupaten Garut?

c. Bagaimana pengaruh pendidikan akhlak dalam keluarga terhadap keperibadian remaja awal (usia 12-15 tahun) di RW.02 Kampung Cibangkerong Desa Mekarmulya Kecamatan Malangbong Kabupaten Garut?

\section{Pengertian Pendidikan Akhlak dalam Keluarga}

Pendidikan akhlak ialah pendidikan perilaku, atau proses mendidik, memelihara, membentuk, dan memberikan latihan mengenai akhlak seseorang, dalam pengertian yang sederhana, pendidikan akhlak diartikan sebagai proses pendidikan akhlak. Dengan demikian pendidikan akhlak merupakan suatu kegiatan yang dilakukan secara sadar dan disengaja untuk memberikan bimbingan, baik 
jasmani maupun rohani, melalui penanaman nilai-nilai islam, latihan moral, fisik, menghasilkan perubahan kearah positif, yang nantinya dapat diaktualisasikan dalam kehidupan, dengan kebiasaan bertingkah laku yang baik, memiliki pemikiran yang jernih dan berbudi pekerti yang luhur menuju terbentuknya manusia yang berakhlak mulia.

Keluarga menurut Undang-Undang Nomor 20 tahun 2003 tentang Sistem Pendidikan Nasional (Sisdiknas) menegaskan bahwa: "Keluarga merupakan pendidikan informal, dimana fungsi dan perannya diharapkan mampu menjembatani sebuah proses (pendidikan) dalam membantu penuntasan fase dan tugas pertumbuhan serta perkembangan peserta didik dalam berbagai kapasitas (intelektual, sosial, emosional, moral, dan fisik) secara maksimal, sehingga pada gilirannya anak-anak akan sukses dalam memasuki dunia yang sesungguhnya dimasa yang akan datang”. (Nana, 2018: 7)

Adapun ruang lingkup pendidikan akhlak menurut Imam Al Ghazali adalah sebagai berikut:
a. Akhlak terhadap Allah
b. Akhlak terhadap orangtua
c. Akhlak terhadap diri sendiri
d. Akhlak terhadap orang lain

Banyak sekali metode-metode dalam usaha pembinaan akhlak. Antara lain pembiasaan akhlak dapat dilakukan melalui beberapa metode, yaitu:

a. Metode Uswah Hasanah (Keteladanan)

Yang dimaksud dengan metode keteladanan yaitu suatu metode pendidikan dengan cara memberikan contoh yang baik didalam ucapan maupun perbuatan.

b. Metode Ta'wid (Pembiasaan)

Pembiasaan merupakan sebuah proses pembentukan keperibadian secara berulang-ulang dalam kehidupan sehari-hari. Proses ini berjalan sampai pada akhirnya tercipta sebuah kebiasaan.

c. Metode Mau'izah (Nasehat)

Melalui metode nasihat, orang tua dapat mengarahkan anaknya. Nasehat disini dapat berupa sebuah tausiyah atau dalam bentuk teguran. Aplikasi metode nasehat diantaranya adalah nasehat dengan argumen logika, nasehat tentang amal ma'ruf nahi munkar, amal ibadah dan lain-lain.

d. Metode Kedisiplinan

Dalam ilmu pendidikan, kedisiplinan sangat ditekankan karena untuk menjaga kelangsungan kegiatan pendidikan. Metode ini sama dengan metode pemberian hukuman. Tujuannya untuk menumbuhkan kesadaran untuk tidak mengulangi pelanggaran yang dilakukannya.

\section{Kepribadian Remaja Awal (Usia 12-15 Tahun)}

Kepribadian menurut Adolf Heukeun, S.J. dkk adalah pola menyeluruh semua kemampuan, perbuatan serta kebiasaan seseorang, baik yang jasmani, mental, 
rohani, mental maupun yang sosial. Semuanya ini telah ditatanya dalam caranya yang khas dibawah beraneka pengaruh dari luar. Pola ini terwujud dalam tingkah lakunya, dalam usahanya menjadi manusia sebagaimana dikehendakinya.

Kepribadian yang dimiliki seseorang tidak lepas dari pengaruh yang datang dari luar dirinya, paling tidak ada tiga faktor utama yang bekerja didalam menentukan perkembangan kepribadian seseorang. Pertama, pengaruh keturunan individu, kedua, pengalaman awal didalam keluarga, ketiga, peristiwa-peristiwa penting dikemudian hari diluar lingkungan rumah. Dengan demikian, pola kepribadian bukanlah hasil belajar secara ekslusif. Sebaliknya, itu berasal dari interaksi dari keduanya.

Menurut Hasan Al Bana yang dikutif oleh Haidar Putra Daulay, sekurangkurangnya ada sepuluh karakter atau ciri khas yang melekat pada pribadi muslim, yaitu:

a Salimul Aqidah (aqidah yang bersih)

b Shahihul Ibadah (ibadah yang benar)

c Mainul Khuluq (akhlak yang kokoh)

d Qowiyyul Jismi (kekuatan jasmani)

e Mutsaqqoful Fikr (intelek dalam berpikir)

f Mujahadatun Linafshi (berjuang melawan hawa nafsu)

g Harishun 'ala Waqtihi (pandai menjaga waktu)

h Munazhzhamun fi Syu'unihi (teratur dalam suatu urusan)

i Qadirun 'alal Kasbi (memiliki kemampuan usaha sendiri atau yang juga disebut dengan mandiri)

j Naafi'un Lighoirihi (bermanfaat bagi oranglain)

Menurut (Jalaludin, 2015: 176) secara garis besar tipe kepribadian manusia ditinjau dari berbagai aspek, antara lain:

a Aspek Biologis

Aspek biologis, yang memengaruhi tipe kepribadian seseorang ini berdasarkan atas konstitusi tubuh dan bentuk tubuh yang dimiliki seseorang.

b Aspek Sosiologis

Pembagian ini didasarkan kepada pandangan hidup dan kualitas sosial seseorang.

c Aspek Psikologis

Dalam pembagian tipe kepribadian berdasarkan psikologis Heyman mengemukakan, bahwa dalam diri manusia terdapat tiga unsur, yaitu: emosionalitas, aktivitas dan fingsi sekunder (proses penggiring).

\section{B. METODE}

\section{Metode Penelitian}

Metode penelitian yang digunakan adalah metode deskriptif dengan penelitian kuantitatif. Metode penelitian ini berusaha untuk menyajikan data dan mengungkapkan fakta-fakta yang sesungguhnya tentang pengaruh pendidikan akhlak 
dalam keluarga terhadap kepribadian remaja awal (usi a12-15 tahun) di RW 02 Kampung Cibangkerong Desa Mekarmulya Kecamatan Malangbong Kabupaten Garut.

\section{Populasi}

Populasi adalah wilayah keseluruhan yang terdiri dari objek/subjek yang mempunyai kualitas dan karakteristik tertentu yang ditetapkan oleh peneliti untuk dipelajari dan kemudian ditarik kesimpulannya. (Wawan, 2015: 119).

Dalam penelitian ini populasinya adalah remaja awal (usia 12-15 tahun) $\mathrm{Rw}$ 02 Kampung Cibangkerong Desa Mekarmulya Kecamatan Malangbong yang berjumlah 135 orang.

\section{Sampel Dan Teknik Sampling}

Sample adalah bagian dari jumlah dan karakteristik yang dimiliki popolasi tersebut. (Wawan, 2015: 120).

Teknik sampling adalah teknik pengambilan sampel dari sebuah populasi (Wawan, 2015: 120).

Teknik sampling yang digunakan pada penelitian ini adalah teknik proportionate Stractified Ramdom Sampling. Teknik proportionate Stractified Ramdom Sampling digunakan untuk menentukan banyaknya sampel dari masingmasing strata dilakukan perhitungan dengan menggunakan rumus dari slovin yang kemudian digunakan Fraction dan setelah itu random, sebagai berikut:

Populasi remaja awal (usia 12-15 tahun) di Rw 02 Kampung Cibangkerong Desa Mekarmulya Kecamatan Malangbong Kabupaten Garut lebih dari 100 orang, yaitu 135 orang maka penarikan sampel adalah dengan rumus Slovin:

Populasi remaja awal (usia 12-15 tahun) di Rw 02 Kampung Cibangkerong Desa Mekarmulya Kecamatan Malangbong Kabupaten Garut lebih dari 100 orang, yaitu 135 orang maka penarikan sampel adalah dengan rumus Slovin:

$$
s=\frac{p}{p d^{2}+1}
$$

Keterangan:

$\mathrm{S}=$ Banyaknya Sampel

$\mathrm{P}=$ Populasi

$d^{2}=$ Prepesi

Prespesi adalah presentase yang diperkirakan oleh peneliti.

Sehingga banyak sampel yang diperoleh, sebagai berikut:

$$
\begin{aligned}
& s=\frac{p}{p d^{2}+1}=\frac{135}{135(0.15)^{2}+1}=\frac{135}{135(0.0225)+1} \\
& s=\frac{135}{3.0375+1}=\frac{135}{4.0375}=33.6=34 \text { (dibulatkan) }
\end{aligned}
$$

Maka sampelnya adalah 34 orang, semua sampel dipilih secara random dengan menggunakan kode nomor.

\section{Teknik Pengumpulan Data}
a. Angket
b. Observasi 

c. Interview (wawancara)
d. Dokumentasi

\section{Teknik Analisis Data}

Untuk mengetahui data tentang pengaruh lingkungan keluarga terhadap akhlak anak yaitu menggunakan langkah-langkah kerja analisis sebagai berikut :

\section{a. Analisis Variabel}

1) Menghitung rata-rata hitung

$$
\bar{x} i \frac{\sum n \cdot x i}{\sum N}
$$

Keterangan :

$$
\bar{X}=\text { nilai rata-rata }
$$

$\mathrm{n}=$ banyak data yang sama

$\mathrm{xi}=$ Jumlah skor $\mathrm{x}$ dalam sekumpulan data

$\mathrm{N}=$ Jumlah populasi

2) Menentukan simpangan rata-rata

$$
\mathrm{SR}=\sum n . i \mathrm{i}
$$

Keterangan :

$\mathrm{n}$ = Banyak data yang sama

$\mathrm{xi}=$ data ke ....i

$$
\bar{X}=\text { rata-rata hitung }
$$

$\mathrm{N}=$ Banyak data tunggal

3) Membuat skala penafsiran dengan banyaknya tingkatan skala mengacu kepada banyaknya option dalam angket.

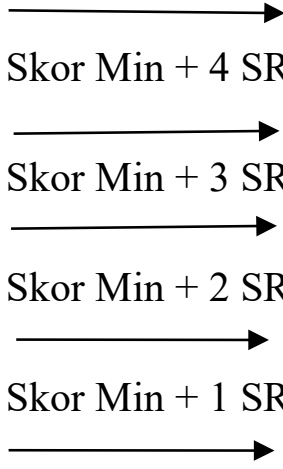

\section{Sangat baik}

\section{Baik}

$$
\text { Cukup baik }
$$

Rendah

\section{$\longrightarrow \quad$ Sangat rendah}

\section{b. Analisis Kolerasi}

1) Menyusun skor data masing-masing variabel $x$ dan $y$.

2) Menyusun urutan data dari yang terkecil hingga terbesar bagi masing-masing variabel (variabel $\mathrm{x}$ dan variabel y).

3) Memberikan posisi pada setiap data yang telah tersusun.

4) Menentukan rangking pada setiap data dengan imbuhannya. Imbuhan rangking diberikan jika ada data yang sama dengan menggunakan rumus $\sum \frac{1}{n}$ dimana $\mathrm{n}=$ banyaknya data yang sama.

5) Menghitung perbedaan rangking dengan rumus $d=r x-r y$. 
$\mathrm{rx}=$ rangking data variabel $\mathrm{x}$

ry = rangking data variabel $\mathrm{y}$

6) Menghitung besarnya koefisien Kolerasi Rank Spearman dari kedua variabel dengan rumus : $\mathrm{rs}=1-6 \sum \mathrm{d}^{2}$

$$
\mathrm{N}^{3}-\mathrm{N}
$$

7) Mengkonfirmasikan koefisien kolerasi rank spearman kepada skala Guilford, yaitu :

$$
\begin{aligned}
& 0,00-0,20 \\
& 0,21 \longrightarrow 0,40 \\
& 0,41-0,60 \\
& 0,61-0,80 \\
& 0,81-1,00
\end{aligned}
$$

8) Menghitung Koefisien Determinasi (KP atau KD) dengan rumus : $K D=r s^{2} x$ $100 \%$

9) Menguji hipotesis dengan rumus cara membandingkan t hitung dengan $t$ tabel, dengan kaidah pengujian :

Jika thitung $\geq \mathrm{t}$ tabel maka Ha diterima dan Ho ditolak

Jika $t$ hitung $\leq \mathrm{t}$ tabel maka Ha ditolak dan Ho diterima

Dengan rumus :

$$
\begin{aligned}
& \mathrm{t} \text { hitung }=\mathrm{rs} \sqrt{\frac{N-2}{1-r s^{2}}} \\
& \mathrm{t} \text { tabel }=\mathrm{t}(1-\propto)(\mathrm{db})=\mathrm{t}(1-\propto)(\mathrm{N}-2)
\end{aligned}
$$

\section{HASIL DAN PEMBAHASAN}

\section{Hasil}

Berdasarkan hasil penelitian pengaruh Pendidikan Akhlak dalam Keluarga terhadap Kepribadian Remaja Awal (Usia 12-15 Tahun) di RW 02 Kampung Cibangkerong Desa Mekarmlya Kecamatan Malangbong Kabupaten Garut, data yang diolah dan di analisis baik secara parsial maupun kolerasi diperoleh sebagai berikut:

Pendidikan Akhlak dama Keluarga di RW 02 Kampung Cibangkerong Desa Mekarmlya Kecamatan Malangbong Kabupaten Garut tergolong baik. Hal ini terbukti setelah dilakukan penyebaran angket kepada 34 responden dengan jumlah item 15 dan menghasilkan skor terkecil 50 dan skor terbesar 71. Besarnya rata-rata hitung yaitu 65 dan rata-rata hitung tersebut berada pada interval $(61,4-65,2)$ dengan klasifikasi baik, artinya bahwa salah satu penyebab adanya pengaruh Pendidikan Akhlak dalam Keluarga ada pengaruh yang signifikan.

Kepribadian Remaja Awal (Usia 12-15 Tahun) di RW 02 Kampung Cibangkerong Desa Mekarmlya Kecamatan Malangbong Kabupaten Garut tergolong cukup baik. Hal ini terbukti setelah dilakukan penyebaran angket kepada 34 responden dengan jumlah item 15 dan menghasilkan skor terkecil 46 dan skor terbesar 63 . Besarnya rata-rata hitung adalah 54 berada pada klasifikasi cukup baik 
dan rata-rata hitung tersebut berada pada interval (52-55) dengan klasifikasi cukup baik.

Pendidikan Akhlak dalam Keluarga terhadap Kepribadian Remaja Awal (Usia 12-15 Tahun) di RW 02 Kampung Cibangkerong Desa Mekarmlya Kecamatan Malangbong Kabupaten Garut tergolong tinggi. Hal ini terbukti dengan hasil kolerasi $r s=0,64$. Pendidikan Akhlak dalam Keluarga terhadap Kepribadian Remaja Awal (Usia 12-15 Tahun) sebesar 40\% sedangkan sisanya 60\% dipengaruhi oleh faktor lain. Kolerasi kedua variabel ini yaitu Pendidikan Akhlak dalam Keluarga terhadap Kepribadian Remaja Awal (Usia 12-15 Tahun) merupakan kolerasi yang signifikan. Hal ini terbukti dengan $t_{\text {hitung }}=4,672>t_{\text {tabel }}=1,69389$, sehingga Ha diterima dan Ho ditolak. Hal ini berarti bahwa hipotesis yang menyatakan terdapat pengaruh Pendidikan Akhlak dalam Keluarga terhadap Kepribadian Remaja Awal (Usia 12-15 Tahun) sehingga penelitian ini dapat diterima.

\section{Pembahasan}

\section{a Hasil Analisis Variabel X (Pendidikan Akhlak dalam Keluarga)}

Dari hasil penelitian diatas, bahwa Pendidikan Akhlak dalam Keluarga terhadap remaja (usia 12-15 tahun) di RW 02 Kampung Cibangkerong Desa Mekarmulya Kecamatan Malangbong Kabupaten Garut tergolong dalam klasifikasi yang baik, artinya bahwa indikator dari metode tersebut sudah memenuhi indikator yang terdapat dalam variabel $\mathrm{X}$.

b Hasil Analisis Variabel Y (Kepribadian Remaja Awal (Usia 12-15 Tahun))

Kepribadian remaja awal (usia 12-15 tahun) di RW 02 Kampung Cibangkerong Desa Mekarmulya Kecamatan Malangbong Kabupaten Garut pada perhitungan statistik diatas pada klasifikasi cukup baik, hal ini dapat disimpulkan bahwa kepribadian remaja awal (usia 12-15 tahun) memerlukan bimbingan lebih lanjut lagi dari keluarga agar kepribadian remaja awal (usia 12-15 tahun) lebih baik.

c Hasil Analisis Korelasi Variabel X dan Y (Pengaruh Pendidikan Akhlak dalam Keluarga terhadap Kepribadian Remaja Awal (Usia 12-15 Tahun))

Berdasarkan hasil penelitian pengaruh Pendidikan Akhlak dalam Keluarga terhadap Kepribadian Remaja Awal (Usia 12-15 Tahun) di RW 02 Kampung Cibangkerong Desa Mekarmulya Kecamatan Malangbong Kabupaten Garut, data yang diolah dan dianalisis baik secara parsial maupun korelasi tergolong tinggi. Hal ini terbukti dengan hasil korelasi $\mathrm{rs}=0,64$ pada skala Guilford berada pada interval 0,61 - 0,80 dengan klasifikasi tinggi. Pendidikan akhlak dalam keluarga mempengaruhi kepribadian remaja awal (usia 12-15 tahun) adalah 40\% sehingga $60 \%$ dipengaruhi oleh faktor lain. Pengaruh kedua variabel ini yaitu pendidikan akhlak dalam keluarga terhadap kepribadian remaja awal usia (usia 12-15 tahun) merupakan korelasi yang signifikan. Hal ini terbukti dengan $t_{\text {hitung }}=4,672>t_{\text {tabel }}=1,69389$, sehingga Ha diterima dan Ho ditolak. Dengan demikian pendidikan akhlak dalam keluarga berpengaruh tinggi terhadap kepribadian remaja awal (usia 12-15 tahun). 


\section{SIMPULAN}

Setelah melakukan penelitian tentang pengaruh pendidikan akhlak dalam keluarga terhadap kepribadian remaja awal (usia 12-15 tahun) di RW 02 Kampung Cibangkerong Desa Mekarmulya Kecamatan Malangbong Kabupaten Garut, penulis menarik kesimpulan sebagai berikut:

1. Pendidikan akhlak dalam keluarga di RW 02 Kampung Cibangkerong Desa Mekarmulya Kecamatan Malangbong Kabupaten Garut berada pada klasifikasi baik, hal ini dibuktikan dengan analisis statistik $\bar{X}$ untuk variabel $\mathrm{X}$ mengenai pendidikan akhlak dalam keluarga di RW 02 Kampung Cibangkerong Desa Mekarmulya Kecamatan Malangbong Kabupaten Garut adalah 65. Maka menurut kriteria perhitungan termasuk baik, yang berada pada skala penafsiran $61,4-65,2$. Dengan ini dapat disimpulkan, bahwa pendidikan akhlak dalam keluarga di RW 02 Kampung Cibangkerong Desa Mekarmulya Kecamatan Malangbong Kabupaten Garut adalah baik.

2. Kepribadian remaja awal (usia 12-15 tahun) di RW 02 Kampung Cibangkerong Desa Mekarmulya Kecamatan Malangbong Kabupaten Garut berada pada klasifikasi cukup baik, hal ini dibuktikan dengan analisis statistik $\bar{X}$ untuk variabel Y mengenai kepribadian remaja awal (usia 12-15 tahun) adalah 54 maka menurut kriteria perhitungan termasuk cukup baik, yang berada pada skala 52-55. Dengan ini dapat disimpulkan bahwa Kepribadian remaja awal (usia 12-15 tahun) di RW 02 Kampung Cibangkerong Desa Mekarmulya Kecamatan Malangbong Kabupaten Garut adalah cukup baik.

3. Pengaruh pendidikan akhlak dalam keluarga terhadap kepribadian remaja awal (usia 12-15 tahun) di RW 02 Kampung Cibangkerong Desa Mekarmulya Kecamatan Malangbong Kabupaten Garut tergolong tinggi. Hal ini terbukti dengan hasil korelasi rs $=0,64$ pada skala Guilford berada pada skala 0,61 - 0,80 dengan klasifikasi tinggi. Artinya bahwa terdapat pengaruh yang signifikan antara pendidikan akhlak dalam keluarga terhadap kepribadian remaja awal (usia 12-15 tahun) di RW 02 Kampung Cibangkerong Desa Mekarmulya Kecamatan Malangbong Kabupaten Garut sebesar 40\% dalam hal ini maka pendidikan akhlak dalam keluarga berpengaruh terhadap kepribadian remaja awal (usia 12-15 tahun) yang lebih baik di RW 02 Kampung Cibangkerong Desa Mekarmulya Kecamatan Malangbong Kabupaten Garut .

Adapun dari hasil uji hipotesis didapatkan nilai $t_{\text {hitung }}=4,672>t_{\text {tabel }}=1,69389$, sehingga Ha diterima dan Ho ditolak. Hal ini berarti bahwa hipotesis yang menyatakan terdapat pengaruh pendidikan akhlak dalam keluarga terhadap kepribadian remaja awal (usia 12-15 tahun) dapat diterima, dalam arti terbukti dan dapat dipercaya. 


\section{DAFTAR PUSTAKA}

Az-Zarnuji. 2009. Panduan Akhlak Guru dan Murid. Semarang: Aneka Ilmu.

Baharudin, Hasan. 2016. Pendidikan Akhlak Dalam Keluarga; TelaahEpistimologis. Pedagogik; Jurnal Pendidikan, Vol. 3 No. 2 (Januari-Juni), 101-103.

Eko Setiawan. 2017. Jurnal Kependidikan, Vol 5 No. 1 Mei 2017 Hakim, Abd. Atang, dan Jaih Mubarok. 2003. “Metodologi Studi Islam”. Bandung. Remaja Rosdakarya.

Husain, Muhammad Isa Ali Manshur. 2017. "Syarah 10 Muwashafat”Solo: Era Intermedia. Jalaluddin. 2017. Psikologi Agama. Jakarta. Raja Grafindo Persada.

Kuntjojo. 2009. Psikologi Keperibadian. Kediri.

Layisa 'Ayisi. 2015. Pengaruh Pendidikan Akhlak Dalam KeluargaTerhadap Perilaku Berbicara Santun Remaja Usia 13-15 Tahun.Skripsi Pendidikan Agama Islam (Tidak Dipublikasikan). Cirebon:Institut Agama Islam Negeri Syekh Nurjati Cirebon.

Latif, Mukhtar dkk. 2014. Orientasi Baru Pendidikan Anak Usia Dini.Jakarta: Kharisma Putra Utama.

Muflihaini. 2017. Implementasi Pendidikan Akhlak Dalam PembentukanKepribadian Muslim. Tesis Pendidikan Agama Islam (Tidak Dipublikasikan). Medan: Universitas Islam Negeri Sumatera Utara.

Mursid. 2016. Pengembangan pembelajaran paud. Bandung: PT Remaja Rosdakarya.

Musyarofah. 2017. Metode Pendidikan Akhlak Menurut Imam Al-Ghazali.Magister Pendidikan Agama Islam (Tidak Dipublikasikan).Malang:Universitas Islam Negeri Maulan Malik Ibrahim Malang.

Nasution, Tika Rizkinda. 2018. "Implementasi Pendidikan Agama Islam Anak Remaja Dalam Keluarga Dilingkungan VIII Kelurahan Bandar Selamat Kecamatan Medan Tembung”. Analytica Islamica, Vol. 7, No. 1 (Januari-Juni), 18.

Nawawi, Hadari. 2007. Metode Penelitian Bidang Sosial. Yogyakarta:Gajah Mada University Press.

Nurmadiah. 2013. "Peranan Pendidikan Agama Dalam Keluarga Terhadap Pembentukan Keperibadian Anak-Anak”. Jurnal Al-Afkar, Vol. II, No. II (Oktober), 91-92.

Prawira, Pura Atmaja. 2013. "Psikologi Kepribadian Dengan Perspektif Baru”. Jogyakarta: Ar-Ruzz Media.

Sholeh. 2016. "Pendidikan Akhlak Dalam Lingkungan Keluarga Menurut Imam Ghazali”. Jurnal Al-Thariqah, Vol. 1 (Juni), 64-65.

Sirait, Ibrahim. 2017. "Implementasi Pendidikan Akhlak Dalam Pengembangan Pendidikan Karakter”. Jurnal Edu Riligia, Vol. No. 4 (Oktober-Desember), 549-550

Suryana, Nana. 2018. Orang tuaku Idolaku Pola Komunikasi Keluarga.Tasikmalaya: Latifah Press.

Syahidin, dkk. 2014. Pendidikan Agama Islam Kontemporer. Jakarta:Yayasan Masyarakat Indonesia Baru.

Syarifudin, Tatang dan Nur'aini. 2006. Landasan Pendidikan. Bandung:Upi Press.

Tafsir, Ahmad. 2008. Ilmu Pendidikan dalam Perspektif Islam. Bandung:Remaja Rosdakarya.

Tafsir, Ahmad. 2013. Metodologi Pengajaran Agama Islam. Bandung: Remaja Rosdakarya 
Tamin, Zulfikri dan Afrizal Nasir. 2015. Akhlak Yang Mulia. Padang:Erlangga. Taqiyuddin. 2008. Pendidikan untuk semua. Bandung: Mulia Press.

Wawan. 2015. Desain Penelitian Kuantitatif. Tasikmalaya: Latifah Press.

Yatimin, Abdullah. 2007. Studi Akhlak dalam Perspektif Islam. Jakarta:Amzah.

Yusuf, M. Kadar. 2012. Tafsir Tarbawi. Yogyakarta: Nusa Media. 